\title{
PREVALENCE OF VITAMIN D DEFICIENCY IN ACUTE CORONARY SYNDROME IN A TERTIARY CARE HOSPITAL, MAHARASHTRA, INDIA
}

\author{
Shilpa Patil1, Piyush Prajapati², Saurabh Gandhi3 ${ }^{3}$, Ajinkya Bahulekar4, Yash Pandey5 , Omkar Patil6, Shivaraj Afzalpurkar7, \\ Srikant Kandagatla ${ }^{8}$

\begin{abstract}
${ }^{1}$ Assistant Professor, Department of Internal Medicine, Krishna Institute of Medical Sciences, Karad.
${ }^{2} 3^{\text {rd }}$ Year Resident, Department of Internal Medicine, Krishna Institute of Medical Sciences, Karad.

${ }^{3} 3^{\text {rd }}$ Year Resident, Department of Internal Medicine, Krishna Institute of Medical Sciences, Karad.

${ }_{4}^{4}{ }^{\text {rd }}$ Year Resident, Department of Internal Medicine, Krishna Institute of Medical Sciences, Karad.

53rd Year Resident, Department of General Surgery, Krishna Institute of Medical Sciences, Karad.

${ }_{63}{ }^{\text {rd }}$ Year Resident, Department of Internal Medicine, Krishna Institute of Medical Sciences, Karad.

${ }^{73}{ }^{\text {rd }}$ Year Resident, Department of Internal Medicine, Krishna Institute of Medical Sciences, Karad.

${ }^{8} 3^{\text {rd }}$ Year Resident, Department of Internal Medicine, Krishna Institute of Medical Sciences, Karad.
\end{abstract}

\begin{tabular}{l}
\hline ABSTRACT \\
BACKGROUND \\
Deficiency in 25-hydroxyvitamin D $(25[\mathrm{OH}] \mathrm{D})$, the main circulating form of vitamin D in blood could be involved in the \\
pathogenesis of Acute Coronary Syndromes $(\mathrm{ACS})$. To date, however, the possible prognostic relevance of $25(\mathrm{OH}) \mathrm{D}$ deficiency in \\
ACS patients remain poorly defined. \\
$\quad$ The purpose of this prospective study was to assess the association between $25(\mathrm{OH})$ D levels in ACS.
\end{tabular}

The purpose of this prospective study was to assess the association between $25(\mathrm{OH})$ D levels in ACS.

\section{MATERIALS AND METHODS}

Total 100 cases were studied in Krishna Institutes of Medical Sciences, Karad. All adult age $>18$ years admitted for acute coronary syndrome were eligible for this study. We measured $25(\mathrm{OH})$ D in 100 ACS patients at hospital presentation; 74\% of them were above the age of 50 years at the time of presentation. The ACS group was studied as STEMI, NSTEMI and unstable angina; $62 \%$ of whom were admitted with STEMI, 20\% NSTEMI and the remaining 18\% with unstable angina. Vitamin D serum levels $>30 \mathrm{ng} / \mathrm{mL}$ were considered as normal; levels between 30 and $21 \mathrm{ng} / \mathrm{mL}$ were classified as insufficiency and levels $<20 \mathrm{ng} / \mathrm{mL}$ as deficiency.

\section{RESULTS}

In the current study, the percentage of Vitamin D deficiency individuals among the study population amounted to $46 \%$ and Vitamin D insufficiency 33\%. No correlation was evident between vitamin D level, age and sex.

\section{CONCLUSION}

Vitamin D deficiency and insufficiency were common in patients with acute coronary syndrome patients.

\section{KEYWORDS}

Vitamin D Level, Acute Coronary Syndrome, Tertiary Care Hospital, Maharashtra.

HOW TO CITE THIS ARTICLE: Patil S, Prajapati P, Gandhi S, et al. Prevalence of vitamin D deficiency in acute coronary syndrome in a tertiary care hospital, Maharashtra, India. J. Evolution Med. Dent. Sci. 2017;6(4):282-285, DOI: 10.14260/Jemds/2017/64

\section{BACKGROUND}

With the turn of the century, Cardiovascular Diseases (CVDs) have become the leading cause of mortality in India.[1] In comparison with the people of European ancestry, CVD affects Indians at least a decade earlier and in their most productive mid-life years.[2,3] For example, in Western populations only $23 \%$ of CVD deaths occur before the age of 70 years; in India this number is $52 \% .{ }^{[4]}$ In addition, case fatality is attributable to CVD in low-income countries including India, appears to be much higher than in middleand high-income countries.[5,6] The World Health Organisation (WHO) has estimated that with the current

Financial or Other, Competing Interest: None.

Submission 27-11-2016, Peer Review 30-12-2016,

Acceptance 06-01-2017, Published 12-01-2017.

Corresponding Author:

Dr. Piyush Prajapati,

IHR Hostel,

Krishna Institute of Medical Sciences, Karad.

E-mail: prajapatipiyush786@gmail.com

DOI: $10.14260 /$ jemds $/ 2017 / 64$ burden of CVD, India would lose $\$ 237$ billion from the loss of productivity and spending on healthcare over a 10-year period (2005 - 2015).[7] Reasons for the high propensity to develop CVD, the high case fatality and the high premature mortality include biological mechanisms, social determinants and their interactions.

Vitamin D deficiency was recently reported to be common in patients with Acute Coronary Syndromes (ACS).[8] Reports from across the world indicate that hypovitaminosis D is widespread and is re-emerging as a major health problem globally.[9] The prevalence of Vitamin D deficiency in urban population is reported from $62 \%-90 \%$ in various ages in India.[10]

Beyond its fundamental role in bone metabolism and calcium homeostasis, vitamin D may influence several other medical conditions including cardiovascular disease. Indeed, vitamin $\mathrm{D}$ receptors have been found in the myocardium as well as in vascular cells and hypovitaminosis $\mathrm{D}$, a common finding in many industrialised countries, has been independently associated with increased risk of developing acute myocardial infarction and heart failure.[11,12]

Moreover, vitamin D deficiency has been linked to conditions such as hypertension, diabetes mellitus, metabolic 
syndrome, cardiac hypertrophy and chronic kidney disease that predispose to cardiovascular disease.[13-17]

More importantly, in heart failure patients vitamin D supplementation has been shown to be associated with improved survival.[18]

Several studies have also demonstrated a survival benefit in end-stage renal disease patients treated with vitamin $\mathrm{D}$, primarily related to a reduction in cardiovascular death.[19] Thus, vitamin D seems to play an important role in cardiac function and in the development and progression of coronary artery disease.

Deficiency of vitamin D or of 25-hydroxyvitamin D (25 $[\mathrm{OH}] \mathrm{D})$, its main circulating form in the blood has been recently reported to be common in patients with Acute Coronary Syndromes (ACS) and preliminary studies indicate a possible association with prognosis.

Very few studies, however, have investigated the association between vitamin D levels and clinical outcomes in ACS patients thus far; moreover, they were either underpowered to evaluate in-hospital outcomes or mainly focused on long-term results. [20-23]

Therefore, convincing data demonstrating the possible impact of vitamin D insufficiency or deficiency, on morbidity and mortality of ACS patients are still lacking. Notably, vitamin D has been demonstrated to suppress the reninangiotensin system and to affect endothelial function, inflammatory processes, platelet function, insulin resistance and blood pressure.[13, 24-27]

All these effects are relevant during ACS and related to patient's clinical course. Moreover, low levels of vitamin D have been associated with ventricular dysfunction and cardiac remodeling after ACS and with heart failure mortality and sudden cardiac death.[20,28,29]

\section{MATERIALS AND METHODS}

Total 100 cases were studied in Krishna Institutes of Medical Sciences, Karad. All adult age $>18$ years admitted for acute coronary syndrome were eligible for this study. Patients were grouped according to their $25(\mathrm{OH})$ D levels within the total number of ACS cases. The ACS group was studied as STEMI, NSTEMI and Unstable Angina. The groups studied were those with vitamin D levels $<20 \mathrm{ng} / \mathrm{mL}, 20-30 \mathrm{ng} / \mathrm{mL},>30 \mathrm{ng} / \mathrm{mL}$ linked to presence of myocardial infarction and ischaemia. ACS was identified on the basis of typical history of angina, ECG changes with or without elevated cardiac enzymes. Patients with history or presence of any of the following were excluded from this study. a) Chronic kidney disease (Creatinine $\geq 2 \mathrm{mg} / \mathrm{dL}$ ), b) Valvular Heart Diseases, c) Congenital Heart Diseases, d) Liver Cirrhosis, Alcoholic Liver Disease, e) Calcium and Vit D supplementation, f) Use of corticosteroids and rifampicin, g) Abnormal calcium levels (Normal reference range - 9 to $11 \mathrm{mg} / \mathrm{dL}$ ), h) Pregnancy/Lactation, i) Diabetes mellitus.

All patients underwent thorough history including time of onset of typical chest pain, nature of pain, increasing with exertion and associated symptoms like excessive sweating and breathlessness. A thorough clinical examination was carried out in each case with special reference to pulse, blood pressure, cardiovascular and respiratory examination for the presence of murmur, crepitations and S3 gallop.

During hospitalisation, complete blood count, urine, fasting and post-prandial blood glucose, blood urea, serum creatinine, liver function tests, chest x-ray, ECG, CPK MB, Troponin-I and 2D echo were done. Venous blood sample sent for vitamin D2 estimation by radioimmunoassay.

According to published data and to the US Endocrine Society guideline recommendations, ${ }^{[30]}$ we used the following cut-off values for classifying vitamin D status: $>30 \mathrm{ng} / \mathrm{mL}$ were considered normal vitamin D levels; between 30 and 21 $\mathrm{ng} / \mathrm{mL}$ were classified as vitamin D insufficiency and $<20$ $\mathrm{ng} / \mathrm{mL}$ as vitamin D deficiency.

\section{RESULTS}

One hundred patients were included in the study (Mean age $58.58,68 \%$ male and $32 \%$ female), $62 \%$ of whom were admitted with STEMI, 20\% NSTEMI and the remaining 18\% with Unstable Angina; $36 \%$ of the patients were between 61 70 years of age and $32 \%$ were between $51-60$ years of age. Thus, over $74 \%$ of them were above the age of $50 \mathrm{yrs}$. at the time of presentation.

\begin{tabular}{|c|c|}
\hline No. of Cases & $\mathbf{1 0 0}$ \\
\hline Male & 68 \\
\hline Female & 32 \\
\hline Mean Age of Year & 58.58 \\
\hline Age range from & $28-85$ \\
\hline Table I. Demographic Data of ACS \\
\hline
\end{tabular}

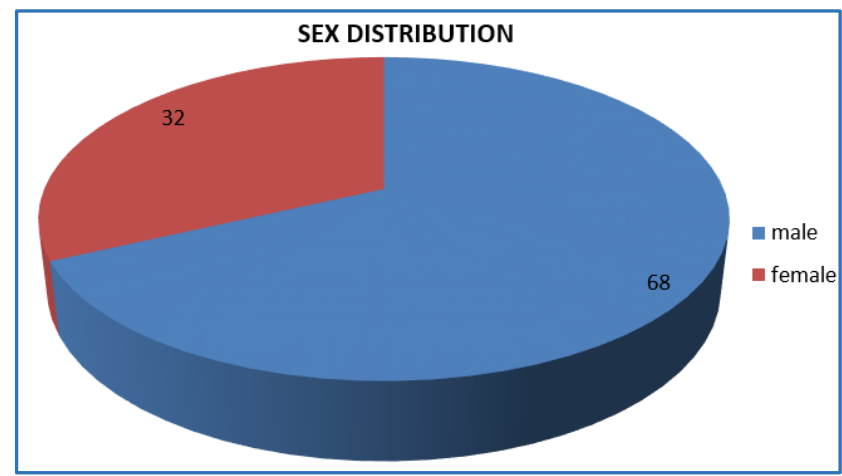

Figure I. Sex Distribution among Study Population

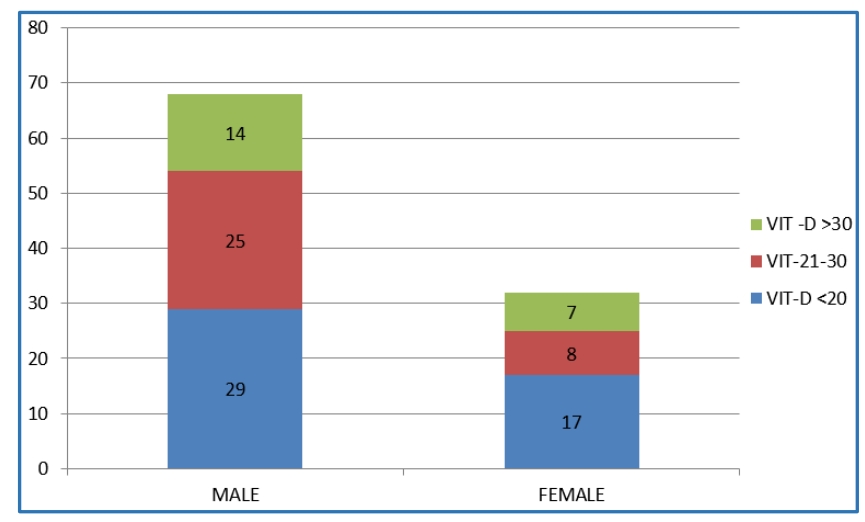

Figure II. Frequency of Vitamin D Level in Male and Female 


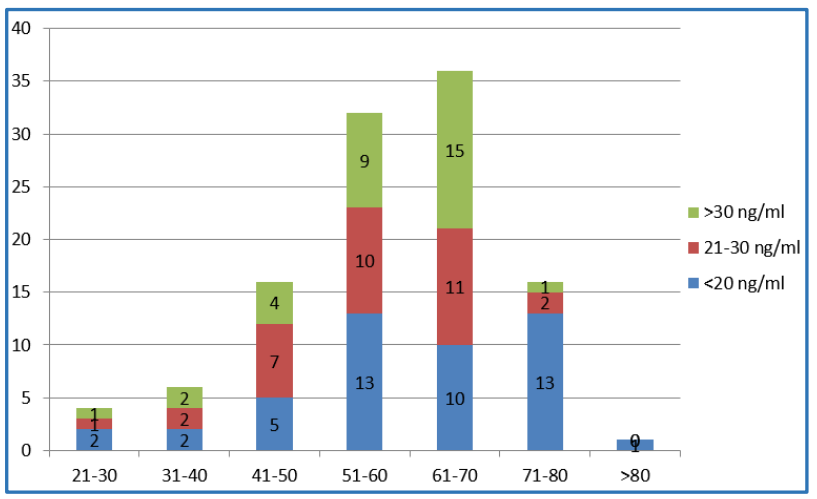

Figure III. Age Distribution among the Study Population with Vitamin D Level

\begin{tabular}{|c|c|c|c|c|}
\hline $\begin{array}{c}\text { Type of } \\
\text { ACS }\end{array}$ & $\begin{array}{c}\text { VIT-D } \\
<\mathbf{2 0} \mathbf{~ n g} / \mathbf{m L}\end{array}$ & $\begin{array}{c}\text { VIT-D } \\
\mathbf{2 1 - 3 0} \mathbf{~ n g} / \mathbf{m L}\end{array}$ & $\begin{array}{c}\text { VIT-D } \\
\mathbf{3 0} \mathbf{~ n g} / \mathbf{m L}\end{array}$ & Total \\
\hline STEMI & 29 & 21 & 12 & 62 \\
\hline NSTEMI & 10 & 6 & 4 & 20 \\
\hline $\begin{array}{c}\text { Unstable } \\
\text { Angina }\end{array}$ & 7 & 6 & 5 & 18 \\
\hline Total & $\mathbf{4 6}$ & $\mathbf{3 3}$ & $\mathbf{2 1}$ & $\mathbf{1 0 0}$ \\
\hline \multicolumn{6}{|l}{ Table II. Frequency of Vitamin D Level in ACS Patients } \\
\hline
\end{tabular}

\section{DISCUSSION}

Coronary heart disease is a leading cause of mortality and morbidity worldwide and elderly people are at special risk (Lopez AD, et al 2006).[31] Vitamin D deficiency is not uncommon and it is associated with cardiovascular risk. A total of 100 patients were included in this study. The mean age of patients with acute coronary syndrome was 58.58 SD \pm 12.38 years, a study conducted in patients enrolled in the Saudi Project for Assessment of Acute Coronary Syndrome (SPACE), in which the mean age of patients was $58 \mathrm{SD} \pm 12.9$ years which supports our study,(31) Khalid AA et al (2012).[32]

Our study showed a preponderance of male among study population. Total male under study were $68 \%$, while the female under study were $32 \%$. Similarly, Hersi A et al (2013) found in a study conducted in coronary syndrome patients, that males were predominant (77\%).[33]

In the current study, the percentage of Vitamin D deficiency individuals among the study population amounted to $46 \%$ and Vitamin D insufficiency 33\%. Similarly, Luis et al (2013) confirmed high vitamin D deficiency among coronary syndrome patients (98\%).

Additionally, Satish K et al (2014) in a study published in India stated that of the patients enrolled $67.5 \%$ were 25 hydroxyvitamin D deficient and $16 \%$ insufficient for a total of $83.5 \%$ of patients with abnormally low 25-vitamin D level and in accordance with the present study.[34]

There is accumulating knowledge about the wide distribution of vitamin D receptors in the cardiovascular system, gastrointestinal tract, muscles, endocrine and others; hence, vitamin D deficiency could participate in the pathogenesis of many diseases including vascular disorders (DeLuca HF, et al 2004).[35]

In the present study, no correlation was evident between vitamin D level, age and sex, similar to Satish K et al (2014), who stated that no significant heterogeneity was observed between age or gender subgroups, but $25(\mathrm{OH}) \mathrm{D}$ deficiency was more commonly seen in those with lower socioeconomic status, lower activity levels, hypercholesterolemia and hypertriglyceridemia.[34]

Several epidemiological studies provided evidence that vitamin D deficiency is associated with atherosclerosis and cardiovascular adverse events in the general population (Brown AJ et al 2007).[36]

\section{CONCLUSION}

Vitamin-D deficiency and insufficiency were common in patients with acute coronary syndrome patients. Further, larger multicentre studies are needed to assess vitamin-D level in acute coronary syndrome patients and to investigate its relationship with long-term prognosis.

\section{REFERENCES}

[1] Reddy SK, Shah B, Varghese C, et al. Responding to the threat of chronic diseases in India. Lancet 2005;366(9498):1744-9.

[2] Joshi P, Islam S, Pais P, et al. Risk factors for early myocardial infarction in South Asians compared with individuals in other countries. JAMA 2007;297(3):286-94.

[3] Xavier D, Pais P, Devereaux PJ, et al. CREATE registry investigators. Treatment and outcomes of acute coronary syndromes in India (CREATE): a prospective analysis of registry data. Lancet 2008;371(9622):1435-42.

[4] Harikrishnan S, Leeder S, Huffman M, et al. A race against time: the challenge of cardiovascular disease in developing economies. $2^{\text {nd }}$ edn. New Delhi, India: New Delhi Centre for Chronic Disease Control 2014.

[5] Yusuf S, Rangarajan S, Teo K, et al. Cardiovascular risk and events in 17 low-, middle-, and high-income countries. N Engl J Med 2014;371(9):818-27.

[6] Prabhakaran D, Yusuf S, Mehta S, et al. Two-year outcomes in patients admitted with non-ST elevation acute coronary syndrome: results of the OASIS registry 1 and 2. Indian Heart J 2005;57(3):217-25.

[7] Mendis S, Puska P, Norrving B. Global atlas on cardiovascular disease prevention and control. Geneva, Switzerland: World Health Organization 2011.

[8] Lee JH, Gadi R, Spertus JA, et al. Prevalence of vitamin D deficiency in patients with acute myocardial infarction. Am J Cardiol 2011;107(11):1636-8.

[9] Mithal A, Wahl DA, Bonjour JP, et al. Global vitamin D status and determinants of hypovitaminosis D. Osteoporos Int 2009;20(11):1807-20.

[10] Mehlawat U, Singh P, Pande S. Current status of vitamin $\mathrm{D}$ deficiency in India. Innovations in Pharmaceuticals and Pharmacotherapy 2014;2(2):328-35.

[11] Lavie CJ, Lee JH, Milani RV. Vitamin D and cardiovascular disease will it live up to its hype? J Am Coll Cardiol 2011;58(15):1547-56.

[12] Vanga RS, Good M, Howard PA, et al. Role of vitamin D in cardiovascular health. Am J Cardiol 2010;106(6):798-805.

[13] Pittas AG, Lau J, Hu FB, et al. The role of vitamin D and calcium in type 2 diabetes: a systematic review and meta-analysis. J Clin Endocrinol Metab 2007;92(6): 2017-29. 
[14] Nainby-Luxmoore JC, Langford HG, Nelson NC, et al. A case-comparison study of hypertension and hyperparathyroidism. J Clin Endocrinol Metab 1982;55(2):303-6.

[15] Saleh FN, Schirmer H, Sundsfjord J, et al. Parathyroid hormone and left ventricular hypertrophy. Eur Heart J 2003;24(22):2054-60.

[16] Holick MF. Vitamin D deficiency. N Engl J Med 2007;357(3):266-81.

[17] Gonzalez EA, Sachdeva A, Oliver DA, et al. Vitamin D insufficiency and deficiency in chronic kidney disease. A single center observational study. Am J Nephrol 2004;24(5):503-10.

[18] Gotsman I, Shauer A, Zwas DR, et al. Vitamin D deficiency is a predictor of reduced survival in patients with heart failure; vitamin D supplementation improves outcome. Eur J Heart Fail 2012;14(4):35766.

[19] Zittermann A, Schleithoff SS, Koerfer R. Vitamin D and vascular calcification. Curr Opin Lipidol 2007;18(1):41-6.

[20] Khalili H, Talasaz AH, Salarifar M. Serum vitamin D concentration status and its correlation with early biomarkers of remodeling following acute myocardial infarction. Clinical Res Cardiology 2012;101(5):321-7.

[21] De Metrio M, Milazzo V, Marenzi G. Serum vitamin D concentration status and its correlation with early biomarkers of remodeling following acute myocardial infarction. Clin Res Cardiol 2012;101(9):771-2.

[22] Correia LC, Sodrè F, Garcia G, et al. Relation of severe deficiency of vitamin D to cardiovascular mortality during acute coronary syndromes. Am J Cardiol 2013;111(3):324-7.

[23] Ng LL, Sandhu JK, Squire IB, et al. Vitamin D and prognosis in acute myocardial infarction. Int J Cardiol 2013;168(3):2341-6.

[24] Li YC. Vitamin D regulation of the renin-angiotensin system. J Cell Biochem 2003;88(2):327-31.

[25] Borges AC, Feres T, Vianna LM, et al. Effect of cholecalciferol treatment on the relaxant responses of spontaneously hypertensive rat arteries to acetylcholine. Hypertension 1999;34(4 Pt 2):897-901.

[26] Schleithoff SS, Zittermann A, Tenderich G, et al. Vitamin D supplementation improves cytokine profiles in patients with congestive heart failure: a double-blind, randomized, placebo-controlled trial. Am J Clin Nutr 2006;83(4):754-9.
[27] Ortega A, Perez de Prada MT, González-Armengol JJ, et al. Effect of parathyroid-hormone-related protein on human platelet activation. Clinical Science 2007;113(7):319-27.

[28] Mancuso P, Rahman A, Hershey SD, et al. 1,25Dihydroxyvitamin-D3 treatment reduces cardiac hypertrophy and left ventricular diameter in spontaneously hypertensive heart failure prone $(\mathrm{cp} /+)$ rats independent of changes in serum leptin. J Cardiovasc Pharmacol 2008;51(6):559-64.

[29] Pilz S, Marz W, Wellnitz B, et al. Association of vitamin $\mathrm{D}$ deficiency with heart failure and sudden cardiac death in a large cross sectional study of patient referred for coronary angiography. J Clin Endocrinol Metab 2008;93(10):3927-35.

[30] Holick MF, Binkley NC, Bischoff-Ferrari HA, et al. Evaluation, treatment, and prevention of vitamin $\mathrm{D}$ deficiency: an endocrine society clinical practice guideline.JClin Endocrinol Metab 2011;96(7):191130.

[31] Lopez AD, Mathers CD, Ezzati M, et al. Global and regional burden of disease and risk factors, 2001: systematic analysis of population health data. Lancet 2006;367(9524):1747-57.

[32] Khalid AA, Hassam FA, Khalid FA, et al. Impact of diabetes on hospital adverse cardiovascular outcomes in acute coronary syndrome patients: data from the Saudi project of acute coronary events. J Saudi Heart Assoc 2012;24(4):225-31.

[33] Hersi A, Al-Habib K, Al-Faleh H, et al. Gender inequality in the clinical outcomes of equally treated acute coronary syndrome patients in Saudi Arabia. Ann Saudi Med 2013;33(4):339-46.

[34] Satish K, Virupakshappa V, Manjunath CN. Study of vitamin $\mathrm{D}$ deficiency prevalence in acute myocardial infarction. IJC Heart \& Vessels 2014;3:57-9.

[35] DeLuca HF. Overview of general physiologic features and functions of vitamin D. Am J Clin Nutr 2004;80(6 Suppl):1689S-96S.

[36] Brown AJ, Slatopolsky E. Drug insight: vitamin D analogs in the treatment of secondary hyperparathyroidism in patients with chronic kidney disease. Nat Clin Pract Endocrinol Metab 2007;3(2):134-44. 